\title{
Cancer Center Organizational Capabilities Section of Cancer Center Support Grant Application
}

National Cancer Institute

\section{Source}

National Cancer Institute. Cancer Center Organizational Capabilities Section of Cancer

Center Support Grant Application. NCI Thesaurus. Code C39339.

The Cancer Center Organizational Capabilities section of the Cancer Center Support Grant Application Form PHS 398 is a part of application describing a cancer center's programmatic structure, administrative organization, advisory groups and decisionmaking committees and processes. 